\title{
Exploratory serosurvey for antibodies to avian pathogens in backyard chickens from a satellite community of Jalapa City, Guatemala
}

\author{
Edvin Aquino-Sagastume ${ }^{1}$, Dennis Guerra-Centeno ${ }^{1 *}$, \\ Carlos Valdez-Sandoval ${ }^{1}$, Federico Villatoro ${ }^{1}$, Daniela Villatoro ${ }^{2}$, Beatriz Santizo ${ }^{3}$ \\ ${ }^{1}$ Instituto de Investigación en Ciencia Animal y Ecosalud, ${ }^{2}$ Laboratorio Clínico y ${ }^{3}$ Laboratorio Regional de Referencia de \\ Sanidad Animal, Facultad de Medicina Veterinaria y Zootecnia, Universidad de San Carlos de Guatemala.
}

*Autor al que se dirige la correspondencia: msc.dennisguerra@gmail.com Recibido: 12 de junio 2016 / Revisión: 14 de julio 2016 / Aceptado: 16 de agosto 2016 / Disponible en línea: 17 de octubre 2016

\begin{abstract}
$\mathrm{A}$ $\mathrm{n}$ exploratory serosurvey was conducted to determine the presence of circulating antibodies to avian pathogens in backyard chickens from Los Achiotes (LAC), a satellite community of Jalapa City, located in eastern Guatemala. Blood samples from 51 adult chickens belonging to 51 households were taken and investigated for the presence of antibodies to Avian Influenza (AI), Newcastle Disease (ND), Infectious Bronchitis (IB), Infectious Bursal Disease (IBD), Mycoplasma gallisepticum (MG) and M. synoviae (MS). Antibodies for AI, ND, were investigated by Hemagglutination Inhibition, for IB and IBD by ELISA (BioChek®) and for MG and MS by a rapid serum plate agglutination test. The cut-off point for positive titers was $1: 4$ for $\mathrm{AI}$ and $\mathrm{ND}$ and a $0.2 \mathrm{~S} / \mathrm{P}$ ratio for IB and IBD. All sampled chickens were positive for concomitant antibodies to various pathogens. Over half of the chickens were positive reactors to antibodies to all six tested pathogens; about a third carried antibodies to five and the rest to four or three. The frequencies of positive reactors were: $\mathrm{AI}=27(53 \%)$; $\mathrm{ND}=49(96.1 \%) ; \mathrm{IB}=$ $50(98 \%) ; \mathrm{IBD}=51(100 \%) ; \mathrm{MG}=45(88 \%)$ and $\mathrm{MS}=48(94 \%)$. The results show that the dynamic population of backyard chickens in LAC could be a potential threat to backyard poultry, farm poultry, wild birds and human population. The need to develop interventions and policies following the One Health approach (animal health to achieve human health) is stressed.
\end{abstract}

Palabras claves: Avian influenza, Newcastle disease, infectious bronchitis, infectious bursal disease, Mycoplasma.

\section{Resumen}

Se realizó un estudio serológico exploratorio buscando anticuerpos contra patógenos aviares en gallinas de traspatio de la comunidad Los Achiotes - una comunidad satélite de la Ciudad de Jalapa, en el oriente de Guatemala-. Se tomaron muestras de sangre de 51 gallinas provenientes de sendas casas. Se buscaron anticuerpos contra influenza aviar (IA), enfermedad de Newcastle (ENC), bronquitis infecciosa (BI), enfermedad de Gumboro (EG), Mycoplasma gallisepticum (MG) y M. synoviae (MS). Para investigar la presencia de anticuerpos contra IA y ENC se utilizó la prueba de inhibición de hemoaglutinación; para los anticuerpos contra BI la prueba de ELISA BioChek ${ }^{\circledR}$ y para los anticuerpos contra MG y MS la prueba rápida en placa. El punto de corte para títulos positivos fue de 1:4 para IA y ENC y de una razón S/P de 0.2 para BI y EG. Todas las gallinas muestreadas portaban concomitantemente anticuerpos contra varios patógenos aviares. Más de la mitad de las gallinas portaban anticuerpos contra los seis patógenos estudiados. Las frecuencias de reactores positivos a anticuerpos fueron: IA $=27$ $(53 \%) ; \mathrm{ENC}=49(96.1 \%) ; \mathrm{BI}=50(98 \%) ; \mathrm{EG}=51(100 \%) ; \mathrm{MG}=45(88 \%)$ y MS = $48(94 \%)$. Se concluye que la población dinámica de gallinas de traspatio de Los Achiotes podría ser una potencial amenaza para la avicultura artesanal, la avicultura tecnificada, las aves silvestres y la población humana. Se señala la necesidad de generar intervenciones y políticas desde la corriente denominada Una salud (salud animal para lograr la salud humana).

Keywords: Influenza aviar, Newcastle, bronquitis infecciosa, Gumboro, Mycoplasma. 


\section{Introduction}

Backyard chicken production is an important resource for rural people in developing countries (Guèye, 2001, 2002, 2005; Sonaiya, Branckaert, \& Guèye, 1999). It is perhaps the most important source of protein accessible for poor peasants (Farrel, 2013; Kitalyi, 1998; Tontisirin, Nantel, \& Bhattacharjee, 2002). In the Spanish colonies of America, chickens have been raised since the XVI century (Sahagún de, 1830; Díaz del Castillo, 2005). As a food source, chicken meat is an important part of the culture of many ethnic groups, and its consumption is customary during social celebrations (Rodríguez et al., 2012). In addition to its use value as food, backyard chickens are also valuable as a commodity for exchange. People sell their chickens when they need to purchase other goods or services such as medicines, food, seeds, fertilizers and construction materials (Aklilu, Udo, Almekinders, \& Van der Zijpp, 2008; Maass et al., 2013).

Although backyard chickens have been raised in Guatemala for almost 500 years, the number of publications in scientific journals concerning the epidemiology of their pathogens is relatively scarce. In other parts of the world, free ranging chicken production systems are characterized by high mortalities caused by infectious diseases, nutritional deficiencies and predators (Aini, 1990; Permin \& Bisgaard, 2013). The presence of avian pathogens in backyard systems could be a source of infection for the domestic poultry industry. Some pathogens such as influenza viruses could also be a source of infection for the human populations. Endemic foci complicate the eradication of avian diseases affecting the exportation of poultry products to countries with sanitary barriers. Backyard chicken populations with pathogens are endemic, and they could also become sources of infection for wild birds, threatening important biological resources in a megadiverse country like Guatemala (Tolisano \& López, 2010). The mortality of backyard chickens directly affect the patrimony of poor farmers and place them in a vulnerable situation.

The aim of this exploratory serosurvey was to search for immunological evidence of exposition to six common avian pathogens in backyard chickens of a satellite community of Jalapa City, Guatemala. This community, called Los Achiotes (LAC), is located at the crossroads of ecological and social conditions that could favor the dissemination of pathogens to humans, wild birds, backyard poultry, industrial poultry and some species of vertebrates.

\section{Material and methods}

\section{Study site}

Los Achiotes is a community of 97 households located near the northern end of the City of Jalapa on the slopes of the Jumay Volcano, Department of Jalapa (N 1440'06.10"; W 8959'39.48') in the eastern area of Guatemala. The average elevation is $1,376 \mathrm{~m}$ above sea level. The location of LAC, some geographical features and the sampling points are shown in Figure 1.

\section{Sampling design}

Considering the compact nature of chicken flocks in backyard systems, the sampling design was based on ecological density-dependent transmission premises (Begon, 2009). Fifty-one households were randomly selected and one chicken was sampled from each one of these households and therefore, from each one of the flock. The householders of the selected households (mostly women), were asked for their permission to sample one chicken and, if agreed, they were asked to select and bring one adult, an apparently healthy individual. None of the participant householders had vaccinated their chickens as it is not a usual procedure in LAC.

\section{Sampling strategy and technique}

All samples were taken on November 23, 2014. A cubic centimeter of blood was collected by puncture of the radial vein using $3 \mathrm{cc}$ syringes with 22 gauge needle $\mathrm{x} 1^{\prime}$. The blood was allowed to stand in a $45^{\circ}$ position at room temperature until the serum was separated. The sera were extracted and placed in $3 \mathrm{cc}$ Vacutainer ${ }^{\circledR}$ tubes without anticoagulant. The tubes were placed in refrigeration and transported to the laboratory the next day.

\section{Sample processing}

The serum samples were tested for antibodies to Avian Influenza (AI), Newcastle Disease (ND), Infectious Bronchitis (IB), Infectious Bursal Disease (IBD), Mycoplasma gallisepticum (MG) and M. synoviae (MS).

Antibodies were tested by various means. AI and $\mathrm{ND}(\operatorname{IgG}, \operatorname{IgM})$ were tested by hemagglutination inhi- 


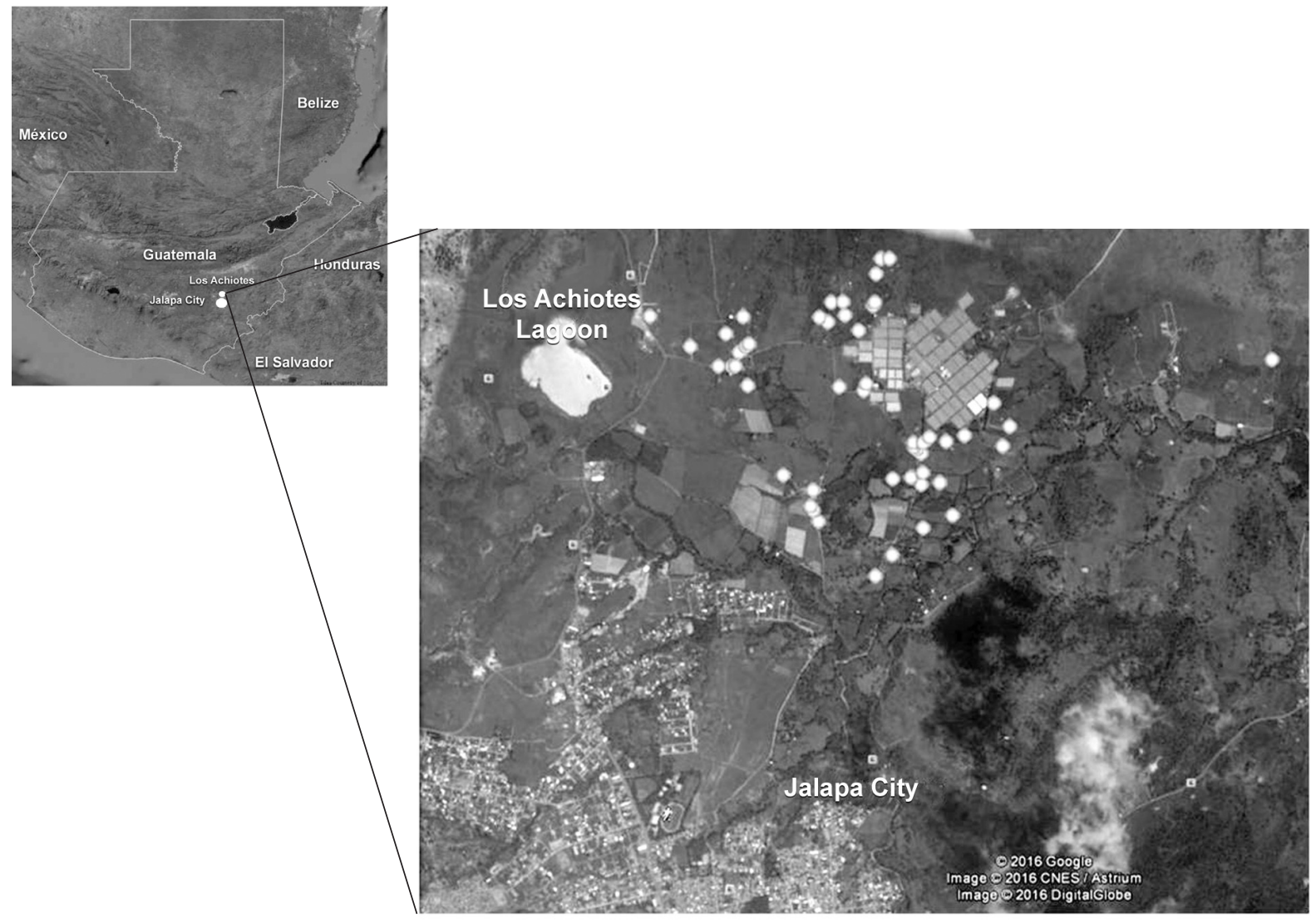

Figure 1. Location of Los Achiotes community, Los Achiotes Lagoon, the northern limit of Jalapa City and the sampling points (dots).

bition using the reference procedure of the World Organization for Animal Health (2016). For testing for IB (IgA, IgG, IgM) and IBD (IgG, IgM), by enzyme-linked immunosorbent assay (Elisa) a Bio-Check ${ }^{\circledR}$ kit was used. For testing for MG (IgM) and MS (IgM), a rapid serum plate agglutination test following the reference procedure of the OIE (2015) was used. All analyses were performed in the Regional Reference Laboratory for Animal Health (Larrsa) at the Veterinary Faculty, University of San Carlos (USAC) in Guatemala. The antigens for $\mathrm{AI}, \mathrm{ND}, \mathrm{MG}$ and $\mathrm{MS}$ tests were prepared in the Larrsa.

Antibody titers for AI and ND were recorded as the highest dilution prior to hemagglutination and for IB and IBD, as Elisa BioChek ${ }^{\circledR}$ titers. Results for MG and MS were nominal (positive or negative). The titer cut-off point for interpreting a positive sample was the $1: 4$ dilution for $\mathrm{AI}$ and $\mathrm{ND}$, and the $0.2 \mathrm{~S} / \mathrm{P}$ ratio for IB and IBD.

\section{Data analysis}

The frequency of response to pathogens was calculated as the percentage of positive reactors to antibodies. The mean titers for AI and ND were calculated as the geometric mean of the reciprocals and the mean titers for IB and IBD were calculated as the arithmetic mean of Elisa titers.

\section{Results}

Antibodies to six pathogens were detected in the blood samples. The frequency of positive reactors was high for all six pathogens, and the overall frequency of positive reactors to antibodies to at least three pathogens was $100 \%$.

The distribution of concomitancy (multi reactors) in the sampled chickens was as follows: $28 / 51$ 
Table 1

Distribution of positive reactors to antibodies to six avian pathogens in chickens of Los Achiotes Community, Jalapa, Guatemala. The " $x$ " indicates presence of antibodies and the blank indicates absence

\begin{tabular}{|c|c|c|c|c|c|c|c|}
\hline Chicken No. & $\mathrm{AI}^{1}$ & $\mathrm{NCD}^{2}$ & $\mathrm{IB}^{3}$ & $\mathrm{IBD}^{4}$ & $\mathrm{MG}^{5}$ & $\mathrm{MS}^{6}$ & $\begin{array}{c}\text { Number of concomitant } \\
\text { antibodies }\end{array}$ \\
\hline 1 & $\mathrm{x}$ & $\mathrm{x}$ & $\mathrm{x}$ & $\mathrm{x}$ & $\mathrm{x}$ & $\mathrm{x}$ & 6 \\
\hline 2 & $\mathrm{x}$ & $\mathrm{x}$ & $\mathrm{x}$ & $\mathrm{x}$ & $\mathrm{x}$ & $\mathrm{x}$ & 6 \\
\hline 3 & $\mathrm{x}$ & $\mathrm{x}$ & $\mathrm{x}$ & $\mathrm{x}$ & $\mathrm{x}$ & $\mathrm{x}$ & 6 \\
\hline 4 & $\mathrm{x}$ & $\mathrm{x}$ & $\mathrm{x}$ & $\mathrm{x}$ & $\mathrm{x}$ & $\mathrm{x}$ & 6 \\
\hline 5 & $\mathrm{x}$ & $\mathrm{x}$ & $\mathrm{x}$ & $\mathrm{x}$ & $\mathrm{x}$ & $\mathrm{x}$ & 6 \\
\hline 6 & $\mathrm{x}$ & & $\mathrm{x}$ & $\mathrm{x}$ & $\mathrm{x}$ & $\mathrm{x}$ & 5 \\
\hline 7 & $\mathrm{x}$ & $\mathrm{x}$ & $\mathrm{x}$ & $\mathrm{x}$ & $\mathrm{x}$ & $\mathrm{x}$ & 6 \\
\hline 8 & $\mathrm{x}$ & $\mathrm{x}$ & $\mathrm{x}$ & $\mathrm{x}$ & $\mathrm{x}$ & $\mathrm{x}$ & 6 \\
\hline 9 & $\mathrm{x}$ & & $\mathrm{x}$ & $\mathrm{x}$ & $\mathrm{x}$ & & 4 \\
\hline 10 & $\mathrm{x}$ & $\mathrm{x}$ & $\mathrm{x}$ & $\mathrm{x}$ & & & 4 \\
\hline 11 & $\mathrm{x}$ & & $\mathrm{x}$ & $\mathrm{x}$ & & & 3 \\
\hline 12 & & $\mathrm{x}$ & $\mathrm{x}$ & $\mathrm{x}$ & & $\mathrm{x}$ & 3 \\
\hline 13 & & $\mathrm{x}$ & $\mathrm{x}$ & $\mathrm{x}$ & & $\mathrm{x}$ & 4 \\
\hline 14 & & $\mathrm{x}$ & $\mathrm{x}$ & $\mathrm{x}$ & $\mathrm{x}$ & $\mathrm{x}$ & 5 \\
\hline 15 & & $\mathrm{x}$ & $\mathrm{x}$ & $\mathrm{x}$ & $\mathrm{x}$ & $\mathrm{x}$ & 5 \\
\hline 16 & $\mathrm{x}$ & $\mathrm{x}$ & $\mathrm{x}$ & $\mathrm{x}$ & $\mathrm{x}$ & $\mathrm{x}$ & 6 \\
\hline 17 & & $\mathrm{x}$ & $\mathrm{x}$ & $\mathrm{x}$ & & $\mathrm{x}$ & 4 \\
\hline 18 & & $\mathrm{x}$ & $\mathrm{X}$ & $\mathrm{x}$ & $x$ & $\mathrm{x}$ & 5 \\
\hline 19 & & $\mathrm{x}$ & $\mathrm{x}$ & $\mathrm{x}$ & $\mathrm{x}$ & $\mathrm{x}$ & 5 \\
\hline 20 & $\mathrm{x}$ & $\mathrm{x}$ & $\mathrm{x}$ & $x$ & $\mathrm{x}$ & $\mathrm{x}$ & 6 \\
\hline 21 & $\mathrm{x}$ & $\mathrm{X}$ & $\mathrm{x}$ & $\mathrm{x}$ & $\mathrm{x}$ & $\mathrm{x}$ & 6 \\
\hline 22 & $\mathrm{x}$ & $\mathrm{X}$ & $\mathrm{x}$ & $\mathrm{x}$ & $\mathrm{x}$ & $\mathrm{x}$ & 6 \\
\hline 23 & $\mathrm{X}$ & $\mathrm{X}$ & $\mathrm{x}$ & $\mathrm{X}$ & $\mathrm{x}$ & $\mathrm{x}$ & 6 \\
\hline 24 & & $\mathrm{x}$ & $\mathrm{x}$ & $\mathrm{x}$ & $\mathrm{x}$ & & 4 \\
\hline 25 & & $\mathrm{x}$ & $\mathrm{x}$ & $\mathrm{x}$ & $\mathrm{x}$ & $\mathrm{x}$ & 5 \\
\hline 26 & $\mathrm{x}$ & $\mathrm{X}$ & $\mathrm{X}$ & $x$ & $\mathrm{x}$ & $\mathrm{x}$ & 6 \\
\hline 27 & $x$ & $\mathrm{x}$ & $\mathrm{x}$ & $\mathrm{x}$ & $\mathrm{x}$ & $\mathrm{x}$ & 6 \\
\hline 28 & $\mathrm{x}$ & $\mathrm{x}$ & $\mathrm{x}$ & $\mathrm{X}$ & $\mathrm{x}$ & $\mathrm{x}$ & 6 \\
\hline 29 & $\mathrm{x}$ & $\mathrm{x}$ & $\mathrm{x}$ & $x$ & $\mathrm{x}$ & $\mathrm{x}$ & 6 \\
\hline 30 & & $\mathrm{X}$ & $\mathrm{x}$ & $\mathrm{X}$ & $\mathrm{x}$ & $\mathrm{x}$ & 5 \\
\hline 31 & & $\mathrm{X}$ & $\mathrm{X}$ & $\mathrm{x}$ & $\mathrm{x}$ & $\mathrm{x}$ & 5 \\
\hline 32 & & $\mathrm{X}$ & $\mathrm{x}$ & $\mathrm{x}$ & $\mathrm{x}$ & $\mathrm{x}$ & 5 \\
\hline 33 & $\mathrm{x}$ & $\mathrm{X}$ & $\mathrm{x}$ & $\mathrm{x}$ & $\mathrm{x}$ & $x$ & 6 \\
\hline 34 & $\mathrm{x}$ & $\mathrm{x}$ & $\mathrm{x}$ & $\mathrm{x}$ & $\mathrm{x}$ & $\mathrm{x}$ & 6 \\
\hline 35 & $\mathrm{x}$ & $\mathrm{x}$ & $\mathrm{x}$ & $\mathrm{x}$ & $\mathrm{x}$ & $\mathrm{x}$ & 6 \\
\hline 36 & $\mathrm{x}$ & $\mathrm{x}$ & $\mathrm{x}$ & $\mathrm{x}$ & $\mathrm{x}$ & $\mathrm{x}$ & 6 \\
\hline 37 & & $x$ & $\mathrm{x}$ & $\mathrm{x}$ & $\mathrm{x}$ & $\mathrm{x}$ & 5 \\
\hline 38 & & $\mathrm{x}$ & $\mathrm{x}$ & $\mathrm{x}$ & $\mathrm{x}$ & $\mathrm{x}$ & 5 \\
\hline 39 & & $\mathrm{X}$ & $\mathrm{x}$ & $\mathrm{x}$ & & & 3 \\
\hline 40 & $\mathrm{X}$ & $\mathrm{x}$ & $\mathrm{x}$ & $x$ & $\mathrm{x}$ & $\mathrm{x}$ & 6 \\
\hline 41 & & $x$ & $\mathrm{x}$ & $\mathrm{x}$ & $\mathrm{x}$ & $x$ & 5 \\
\hline 42 & & $\mathrm{x}$ & $\mathrm{X}$ & $\mathrm{X}$ & $\mathrm{x}$ & $\mathrm{x}$ & 5 \\
\hline 43 & & $\mathrm{X}$ & $\mathrm{x}$ & $\mathrm{x}$ & $\mathrm{x}$ & $\mathrm{x}$ & 5 \\
\hline 44 & $\mathrm{x}$ & $\mathrm{X}$ & $\mathrm{x}$ & $\mathrm{X}$ & $\mathrm{X}$ & $\mathrm{X}$ & 6 \\
\hline
\end{tabular}

Note. ${ }^{1}$ Avian Influenza, ${ }^{2}$ Newcastle Disease, ${ }^{3}$ Infectious Bronchitis, ${ }^{4}$ Infectious Bursal Disease, ${ }^{5}$ Mycoplasma gallisepticum, ${ }^{6}$ M. sinoviae. 
Table 1, continuation

$\begin{array}{cccccccc}45 & \mathrm{x} & \mathrm{x} & \mathrm{x} & \mathrm{x} & \mathrm{x} & \mathrm{x} & 6 \\ 46 & \mathrm{x} & \mathrm{x} & \mathrm{x} & \mathrm{x} & \mathrm{x} & \mathrm{x} & 6 \\ 47 & \mathrm{x} & \mathrm{x} & \mathrm{x} & \mathrm{x} & \mathrm{x} & \mathrm{x} & 6 \\ 48 & & \mathrm{x} & \mathrm{x} & \mathrm{x} & \mathrm{x} & \mathrm{x} & 6 \\ 49 & \mathrm{x} & \mathrm{x} & \mathrm{x} & \mathrm{x} & \mathrm{x} & \mathrm{x} & 6 \\ 50 & \mathrm{x} & \mathrm{x} & \mathrm{x} & \mathrm{x} & \mathrm{x} & \mathrm{x} & 6 \\ 51 & \mathrm{x} & \mathrm{x} & \mathrm{x} & \mathrm{x} & \mathrm{x} & \mathrm{x} & \\ \begin{array}{c}\text { Number of } \\ \text { positive }\end{array} & 32 & 48 & 51 & 51 & 45 & 46 & \\ \text { chickens } & & & & & & & \end{array}$

Note. ${ }^{1}$ Avian Influenza, ${ }^{2}$ Newcastle Disease, ${ }^{3}$ Infectious Bronchitis, ${ }^{4}$ Infectious Bursal Disease, ${ }^{5}$ Mycoplasma gallisepticum, ${ }^{6}$ M. sinoviae.

sera $(58 \%)$ were positive to antibodies to six pathogens; $15 / 51$ sera $(29 \%)$ were positive to antibodies to five pathogens; $5 / 51$ sera $(10 \%)$ were positive to antibodies to four pathogens and $3 / 51$ sera $(6 \%)$ were positive to antibodies to three pathogens.

The observed frequencies of positive reactors to pathogens were: $\mathrm{AI}=27 / 51$ samples $(53 \%)$; $\mathrm{ND}=$ 49/51 samples $(96.1 \%)$; IB $=50 / 51$ samples $(98 \%)$; IBD $=51 / 51$ samples $(100 \%) ; \mathrm{MG}=45 / 51$ samples $(88 \%)$ and $\mathrm{MS}=48 / 51$ samples $(94 \%)$. The distribution of positive reactors to antibodies to the selected pathogens is shown in Table 1. The geometric mean titers were 4.22 for AI, 17.84 for ND, 5354 for IB and 5681 for IBD.

\section{Discussion}

Chicken owners interviewed during the sampling phase of this research stated that chicken vaccination practices are absent in LAC. Therefore, it is assumed that any detected circulating antibodies resulted from the exposure to field pathogens (Chaka, Goutard, Bisschop, \& Thompson, 2012). The possibility of non-specific reactions is low because to our knowledge, no humoral cross-reactions have been described between the studied pathogens.

The serological evidence indicating the presence of all six tested pathogens in the sampled chickens of LAC is not surprising. It is, in fact, a reflex of the complex community of endemic parasites to Guatemala. Moreover, the finding of chickens carrying concomitantly antibodies to six pathogens suggests simultaneous and multiple challenges. Concomitant parasite infections are common in host populations from developing countries (Petney \& Andrews, 1998). Never- theless, this could also be an indicator of vitality and resistance traits held by chickens that struggle to survive these multiple challenges.

It is known that several subtypes of AI virus circulate in Guatemala. The subtype H5N2 has been found in domestic fowl (Lee, Senne, \& Suarez, 2004) and subtypes H7N9, H11N2, H3N8, H5N3, H8N4 and H5N4 in wild birds (González-Reiche et al., 2012; González-Reiche \& Perez, 2012). The current evidence indicates that the main carrier of AI viruses in Guatemala is the blue-winged teal (Anas discors L.) (González-Reiche et al., 2012). This migratory bird species is widely distributed in the country including the Department of Jalapa (Howell \& Webb, 1995). On the west edge of LAC, there is a lagoon (Laguna Los Achiotes, shown in Figure 1) which is visited by migratory waterfowl and is, therefore, a potential site for virus-host contact. During their migration, ducks -such as the bluewinged teal- use to stop at wetlands where they can meet other domestic or wild birds.

The high proportion of positive reactors to ND in chickens of LAC is a relevant finding because this disease is considered to be the most devastating for backyard chickens in rural areas (Aini, 1990; Alexander, 2000; Alexander, Bell, \& Anders, 2004; Lomniczi et al., 1998). The fact that almost all chickens in LAC were positive to antibodies to ND could be an indicator of the pervasiveness of this virus in Guatemala. Although transmission commonly occurs from chicken to chicken, ducks and other wild migratory birds could also act as disseminators of the virus to backyard chickens (Onapa, Christensen, Mukiibi, \& Bisgaard, 2006; Shim, So, Wong, \& Mo, 2011).

The finding of IB evidence, has ecological and economic implications. It has ecological implications 
because it is an easily transmitted virus with multiple serotypes and poor ability to generate cross immunogenicity in hosts (Cavanagh \& Gelb, 2003), and therefore poses a threat of transmission to other domestic and wild birds. Economically, this disease is a major cause of economic losses in the poultry industry (Cavanagh, 2007) and one of the most difficult to control through vaccination programs.

The high frequency of antibodies to IBD is also interesting since this is an immunosuppressive virus (Sharma, Kim, Rautenschlein, \& Yeh, 2000). The infection with IBD could at least partially explain the episodes of post-vaccination illness referred by farmers in other communities like Aldea El Caoba, in northern Guatemala (M. Córdova, August 15, 2013, personal communication). It is known that IBD affects the ability of chickens to respond to ND, IB and Mycoplasma inoculations (Giambrone, Eidson, \& Kleven, 1977).

It is interesting however that all the chickens sampled in this study were survivors to a previous exposition to IBD virus. An immunocompromised individual could hardly withstand a multifaceted challenge and manage to survive and respond with antibodies to all antigens to which it has been exposed. The effects of IBD exposition in backyard chickens warrants further investigation.

Mycoplasma gallisepticum and M. synoviae, have been identified as common opportunistic pathogens causing mortality, reduced egg production, and low feed conversion in poultry (Siddique, Rahman, Hussain, \& Muhammad, 2012). The importance of having found circulating antibodies to these Mycoplasma species lies in the fact that, in addition to exert direct effects on the health of hosts, such pathogens often complicate the clinical pictures of other avian diseases such as ND and IB (Kleven, 1998).

Besides the natural dispersion, the farmer-mediated dynamics that occur when chicken populations are being restored after a "pest" outbreak contributes to the dissemination and circulation of the parasite community (including microbes). The farmers contacted in this study indicated that after losing their flock, they usually get replacement chickens from the same or from distant communities. At the landscape scale, this chicken population dynamics, and by extension, the parasite population dynamics, could correspond to a metapopulation model (Levins, 1969) where a mutable sources and sinks stage are developed and maintained in the households of LAC (Pulliam, 1998).
The commerce of poultry and poultry products from Mexico to Guatemala (García-García \& Ramos, 2006) could also be a contributing factor for the dissemination of viruses in the landscapes of Guatemala. This dynamics poses a risk of intermittent contagion and spread of pathogens to birds and other vertebrates, including humans.

Los Achiotes community is a satellite village of Jalapa City, where more than 300,000 people live (Programa de Naciones Unidas para el Desarrollo [PNUD] Guatemala, 2011). It is known that the most deadly outbreaks of avian influenza have emerged from mutations of avian viruses (Garten et al., 2009; Gerloff et al., 2014; Kim et al., 2014). Influenza viruses can stay and mutate in other vertebrate host species (Lu, Lycett, \& Brown, 2014). Given the ecological and social conditions of LAC, the presence of circulating AI viruses -even low pathogenic forms- in the chicken population, could become a matter of public health.

One might be prone to think that chickens that now survive in the backyards of rural households of Guatemala belong to a super resistant breed of Gallus gallus L., created by semi-natural genetic selection processes ongoing from hundreds of years. Nevertheless, the occurrence of virus epidemics which decimate entire populations of backyard chickens -called accident or pest in Guatemala- are common in poor countries (Permin \& Bisgard, 2013). These outbreak episodes can also be complicated by bacteria and other parasites which are also prevalent and common in backyard scavenger chicken populations (Colles et al., 2008; Dahl et al., 2002; Dubey et al., 2007). When an outbreak of accident is approaching, it is likely that some farmers rush to sell their chickens to markets (Mallia, 1999), often contributing to the spread of prevalent avian pathogens. Unlike what happens in confinement production systems that can achieve adequate levels of biosecurity, backyard production is characterized by a high risk of acquiring infections (Dahl et al., 2002).

The six species of pathogens circulating in the backyard chicken flocks of LAC are probably only a part of the diversity of pathogens in the agricultural ecosystem (Petney \& Andrews, 1998). In a recent study, multiple infections have also been found in backyard chickens from a northern rural community of Guatemala (Aguilar-Miller, Guerra-Centeno, Valdéz-Sandoval, Monterroso, \& García, 2016). It is possible that certain environmental conditions characterized by an abundance of resources favor the natural resistance of chickens to multiple exposure to pathogens (Beldome- 
nico \& Begon, 2010). However, out of that period of surplus, when resources become scarce and environmental stress increases, the immune system of chickens could succumb, allowing the exacerbation of multiple pathogens (Alexander, Bell, \& Anders, 2004) and the raising of mortality.

The findings of the present study lead us to formulate some hypotheses that are interesting. (1) The genetic selection that backyard chicken populations have undergone, since their introduction to Guatemala in the sixteenth century, has produced individuals resistant to challenges of a certain magnitude and frequency; (2) Multiple resistance is not sufficient to cope with the conditions occurring during times of the year when food is scarce and the environment becomes unfavorable or offensive; (3) The population dynamics (immigration, emigration, mortality and birth) observed at the intraand inter- scales, enables and favors the persistence of pathogens in the environment, establishing metapopulations and sources and sinks systems (Pulliam, 1988); (4) The unfavorable weather conditions, the presence of pathogens in the environment and the poor condition of chickens at the end of the dry season, favors the emergence of accident or pest disease outbreaks; (5) The persistence of pathogens in LAC could pose a health risk to domestic and wild birds and to human populations, especially considering the proximity of this community to a populated city, a lagoon, a river and a natural protected area (Jumay Volcano).

The high frequencies of multiple reactors to antibodies to common avian diseases observed in LAC suggest that these diseases could be somehow neglected or underserved by social actors normally responsible to promote livestock health and productivity. The limited number of scientific publications about epidemiology of common diseases in backyard chickens from Guatemala reinforces the hypothesis that this issue is somehow neglected or disregarded.

Although the presence of pathogens is recognized as an outbreak risk, backyard chickens are such a valuable resource for the rural poor farmers that we are morally obligated to seek viable and efficient ways to maintain and raise the productivity of this species without affecting the balance and sustainability of agro ecosystems. The importance and convenience of improving animal health from the One Health approach, through public policies and interventions to achieve improvements in the quality of life for poor farmers, has recently been recognized (Stringer, 2014) and is strongly recommended for the case of LAC.

\section{Acknowledgments}

The authors thank Juan Pablo Sagastume and Eduardo Aquino for their collaboration in the field sampling and exploratory social research. The authors also thank the participants of LAC for providing permission for taking blood samples from their chickens.

\section{References}

Aini, I. (1990). Indigenous chicken production in South-east Asia. World's Poultry Science Journal, 46(01), 51-57.

Aguilar-Miller, H. J., Guerra-Centeno, D. S., ValdézSandoval, J. C., Monterroso, P., \& García, R. (2016). Estudio serológico de anticuerpos contra patógenos comunes, en gallinas de patio de la aldea El Caoba, Reserva de la Biosfera Maya, Guatemala. Revista Naturaleza, Sociedad y Ambiente, 3, 95-106.

Aklilu, H. A., Udo, H. M., Almekinders, C. J., \& Van der Zijpp, A. J. (2008). How resource poor households value and access poultry: Village poultry keeping in Tigray, Ethiopia. Agricultural Systems, 96(1-3), 175-183.

Alexander, D. J. (2000). Newcastle disease and other avian paramyxoviruses. Revue Scientifique et Technique (Office International des Epizooties), 19(2), 443-462.

Alexander, D. J., Bell, J. G., \& Alders, R. G. (2004). A technology review: Newcastle disease, with special emphasis on its effect on village chickens (No. 161). Roma: Food \& Agriculture Organization.

Begon, M. (2009). Ecological epidemiology. In Levin, S. A., Carpenter, S. R., Charles, H., Godfray, J., Kinzig, A. P., Loreau, M., Losos, J. B., Walker, B., \& Wilcove, D. S. (Eds), The Princeton guide to ecology (pp. 220-226). Princeton: Princeton University Press.

Beldomenico, P. M., \& Begon, M. (2010). Disease spread, susceptibility and infection intensity: Vicious circles? Trends in Ecology \& Evolution, 25(1), 21-27. 
Cavanagh, D. (2007). Coronavirus avian infectious bronchitis virus. Veterinary Research, 38(2), 281297. doi: $10.1051 /$ vetres:2006055

Cavanagh, D., \& Gelb, J. (2003). Infectious bronchitis. In Y. M. Saif (Ed.), Diseases of poultry (pp. 117134). New Jersey: Blackwell Publishing.

Chaka, H., Goutard, F., Bisschop, S. P. R., \& Thompson, P. N. (2012). Seroprevalence of Newcastle disease and other infectious diseases in backyard chickens at markets in Eastern Shewa zone, Ethiopia. Poultry Science, 91(4), 862-869. doi: 10.3382/ ps.2011-01906

Colles, F. M., Jones, T. A., McCarthy, N. D., Sheppard, S. K., Cody, A. J., Dingle, K. E., ... Maiden, M. C. (2008). Campylobacter infection of broiler chickens in a free-range environment. Environmental Microbiology, 10(8), 2042-2050. doi:10.1111/j.1462-2920.2008.01623.x

Dahl, C., Permin, A., Christensen, J. P., Bisgaard, M., Muhairwa, A. P., Petersen, K. M. D., ... Jensen, A. L. (2002). The effect of concurrent infections with Pasteurella multocida and Ascaridia galli on free range chickens. Veterinary Microbiology, 86(4), 313-324.

Díaz del Castillo, B. (2005). La verdadera historia de la conquista de la Nueva España. México: Porrúa.

Dubey, J. P., Sundar, N., Gennari, S. M., Minervino, A. H., Farias, N. D., Ruas, J. L., ... Su, C. (2007). Biologic and genetic comparison of Toxoplasma gondii isolates in free-range chickens from the northern Pará state and the southern state Rio Grande do Sul, Brazil revealed highly diverse and distinct parasite populations. Veterinary Parasitology, 143(2), 182-188. doi:10.1016/j. vetpar.2006.08.024

Farrell, D. (2013). Función de las aves de corral en la nutrición humana. In Food \& Agriculture Organization, Revisión del desarrollo avícola (pp. 2-3). Roma: FAO.

García-García, J., \& Ramos, C. (2006). La influenza, un problema vigente de salud pública. Salud Pública de México, 48(3), 244-267.

Garten, R. J., Davis, C. T., Russell, C. A., Shu, B., Lindstrom, S., Balish, A., ... Cox, N. J.. (2009). Antigenic and genetic characteristics of swine-origin 2009 A (H1N1) influenza viruses circulating in humans. Science, 325(5937), 197201. doi: 10.1126/science. 1176225

Gerloff, N. A., Khan, S. U., Balish, A., Shanta, I. S., Simpson, N., Berman, L., ... Davis, C. T. (2014). Multiple reassortment events among highly pathogenic avian influenza A (H5N1) viruses detected in Bangladesh. Virology, 450-451, 297307. doi:10.1016/j.virol.2013.12.023

Giambrone, J. J., Eidson, C. S., \& Kleven, S. H. (1977). Effect of infectious bursal disease on the response of chickens to Mycoplasma synoviae, Newcastle disease virus, and infectious bronchitis virus. American Journal of Veterinary Research, 38(2), 251-253.

González-Reiche, A. S., Morales-Betoulle, M. E., Alvarez, D., Betoulle, J. L., Müller, M. L., Sosa, S. M., \& Perez, D. R. (2012). Influenza a viruses from wild birds in Guatemala belong to the North American lineage. PloS ONE, 7(3): e32873. doi:10.1371/journal.pone.0032873.

González-Reiche, A. S., \& Perez, D. R. (2012). Where do avian influenza viruses meet in the Americas? Avian Diseases, 56(4s1), 1025-1033.

Guèye, E. F. (2001). Marketing of family poultry products in Africa to be improved. World Poultry, $17(5), 12-16$.

Guèye, E. F. (2002). Employment and income generation through family poultry in low-income food-deficit countries. World's Poultry Science Journal, 58(4), 541-557.

Guèye, E. F. (2005). Gender aspects in family poultry management systems in developing countries. World's Poultry Science Journal, 61(1), 39-46.

Howell, S. N., \& Webb, S. (1995). A guide to the birds of Mexico and northern Central America. Oxford: Oxford University Press.

Kim, Y. I., Pascua, P. N. Q., Kwon, H. I., Lim, G. J., Kim, E. H., Yoon, S. W., ... Choi, Y. K. (2014). Pathobiological features of a novel, highly pathogenic avian influenza A (H5N8) virus. Emerging Microbes \& Infections, 3(10), e75. doi: 10.1038/emi.2014.75

Kitalyi, A. J. (1998). Village chicken production systems in rural Africa: Household food security and gender issues (Vol. 142). Roma: Food and Agriculture Organization. 
Kleven, S. H. (1998). Mycoplasmas in the etiology of multifactorial respiratory disease. Poultry Science, 77(8), 1146-1149.

Lee, C. W., Senne, D. A., \& Suarez, D. L. (2004). Effect of vaccine use in the evolution of Mexican lineage $\mathrm{H} 5 \mathrm{~N} 2$ avian influenza virus. Journal of Virology, 78(15), 8372-8381. doi: 10.1128/JVI.78.15.83728381.2004

Levins, R. (1969). Some demographic and genetic consequences of environmental heterogeneity for biological control. Bulletin of the Entomological Society of America, 15(3), 237-240.

Lomniczi, B., Wehmann, E., Herczeg, J., BallagiPordany, A., Kaleta, E. F., Werner, O., ... Damoser, J. (1998). Newcastle disease outbreaks in recent years in Western Europe were caused by an old (VI) and a novel genotype (VII). Archives of Virology, 143(1), 49-64.

Lu, L., Lycett, S. J., \& Brown, A. J. (2014). Reassortment patterns of avian influenza virus internal segments among different subtypes. $B M C$ Evolutionary Biology, 14(1), 16.

Maass, B. L., Chiuri, W. L., Zozo, R., KatungaMusale, D., Metre, T. K., \& Birachi, E. (2013). Using the 'livestock ladder' as a means for poor crop-livestock farmers to exit poverty in Sud Kivu province, eastern DR Congo. In B. Vanlauwe, P. Van Asten, \& G. Blomme (Eds.), Agro-Ecological intensification of agricultural systems in the African highlands (pp. 145-155). London: Earthscan, Routledge.

Mallia, J. G. (1999). Observations on family poultry units in parts of Central America and sustainable development opportunities. Livestock Research for Rural Development, 11(3).

Onapa, M. O., Christensen, H., Mukiibi, G. M., \& Bisgaard, M. (2006). A preliminary study of the role of ducks in the transmission of Newcastle disease virus to in-contact rural free-range chickens. Tropical Animal Health and Production, 38(4), 285-289. : doi: 10.1007/s11250-006-4309-4

Permin, A., \& Bisgaard, M. (2013). A general review on some important diseases in free-range chickens. In Food \& Agriculture Organization, The scope and effect of family poultry research and development. First INFPD/FAO Electronic Conference on Family Poultry (pp. 163-167). Rome: FAO.
Petney, T. N., \& Andrews, R. H. (1998). Multiparasite communities in animals and humans: Frequency, structure and pathogenic significance. International Journal for Parasitology, 28(3), 377-393. doi:10.1016/S0020-7519(97)00189-6

Programa de las Naciones Unidas (2011). Cifras para el desarrollo humano Jalapa (Colección Estadística Departamental, Fascículo 21). Guatemala: Autor.

Pulliam, H. R. (1988). Sources, sinks, and population regulation. American Naturalist, 132(5), 652-661.

Rodríguez, G., Sanabria, N., Ramírez, C., Guevara, F., Perezgrovas, R., \& Zaragoza, L. (2012). La gallina de rancho y el caldo de gallina como elementos de identidad campesina frailescana. Actas Iberoamericanas de Conservación Animal, 2, 25-34.

Sahagún de, B. (1830). Historia general de las cosas de Nueva España. (Tomo tercero). In C. M. de Bustamante (Ed.). México: Imprenta del Ciudadano Alejandro Valdés

Sharma, J. M., Kim, I. J., Rautenschlein, S., \& Yeh, H. Y. (2000). Infectious bursal disease virus of chickens: Pathogenesis and immunosuppression. Developmental \& Comparative Immunology, 24(23), 223-235. doi:10.1016/S0145-305X(99)00074-9

Shim, J.-B., So, H.-H., Won, H.-K., \& Mo, I.-P. (2011). Characterization of avian paramyxovirus type 1 from migratory wild birds in chickens. Avian Pathology, 40(6), 565-572. doi: 10.1080/03079457.2011.616187

Siddique, A. B., Rahman, S. U., Hussain, I., \& Muhammad, G. (2012). Frequency distribution of opportunistic avian pathogens in respiratory distress cases of poultry. Pakistan Veterinary Journal, 32(3), 386-389.

Sonaiya, E. B., Branckaert, R. D. S., \& Guèye, E. F. (1999). Research and development options for family poultry. In Food \& Agriculture Organization, The scope and effect of family poultry research and development. First INFPD/FAO Electronic Conference on Family Poultry (pp. 3-18). Rome: Food and Agriculture Organization.

Stringer, A. (2014). Improving animal health for poverty alleviation and sustainable livelihoods. Veterinary Record, 175(21), 526-529. doi:10.1136/vr.g6281 
Tolisano, J., \& Lopez, M. M. (2010). Guatemala biodiversity and tropical forest assessment. Washington: United States Agency for International Development.

Tontisirin, K., Nantel, G., \& Bhattacharjee, L. (2002). Food-based strategies to meet the challenges of micronutrient malnutrition in the developing world. Proceedings of the Nutrition Society, 61(2), 243-250.

World Organization for Animal Health (2016). Manual of diagnostic tests and vaccines for terrestrial animals 2016. [Web version]. Retrieved from http://www.oie.int/international-standard-setting/ terrestrial-manual/access-online/ 